\title{
Assessment of the Effects of Beauveria bassiana (Hypocreales) Inoculum on the Composting of Vegetable Wastes
}

\author{
Nomfusi Ntsobi, Ninon G.E.R. Etsassala, Enoch A. Akinpelu and F. Nchu*
}

\begin{abstract}
Microbial inocula are explored as agents for the optimization of composting process. This present research work primarily evaluates the efficacy of inoculating organic vegetable heaps with the entomopathogenic fungus Beauveria bassiana (Hypocreales) on the biophysicochemical properties of the end-product of composting. Five heaps of fresh vegetable wastes were inoculated with conidial inoculum of $B$. bassiana, while another five were not exposed to the fungus. The heaps were composted for four weeks. The biophysicochemical characteristics of the heaps were determined. Additionally, phytoxicity tests of the composted materials were carried out at the end of the experiment. We found no significant differences $(\mathrm{P}>0.05)$ in heap temperatures and heap moisture levels between the fungus and control treatments. While the levels of most of the macronutrients $(\mathrm{N}, \mathrm{P}, \mathrm{K}$ and $\mathrm{Mg}$ ) did not differ significantly between the two treatments $(\mathrm{df}=1,6 ; \mathrm{P}>0.05)$, remarkably, end-product of composted heaps exposed to $B$. bassiana inoculum showed significantly ( $\mathrm{df}=1,6 ; \mathrm{P}<0.05$ ) higher levels of $\mathrm{Mn}, \mathrm{Fe}, \mathrm{Cu}$ and $\mathrm{Zn}$. The phytotoxicity tests revealed that the composted samples from fungus treated heaps showed a diminished toxicity to cowpea seeds and seedlings when end-product of composting were used at higher concentration (25\%) compared to $(12.5 \%)$ in a soil mix. In conclusion, this study showed that $B$. bassiana inoculum induced significant increases in micronutrient contents and moderate phytoxicity of composted materials following composting of vegetable wastes.
\end{abstract}

Keywords - Composting, Organic vegetable wastes, Inoculation, Beauveria bassiana, Microbial count, Toxicity

\section{INTRODUCTION}

The increasing demand for organic farm produce globally has spurred farmers to adopt more sustainable farming practices [1]. Farmers are increasingly turning their backs to conventional farming, which is characterized by the persistent use of synthetic fertilizers [2]. There is a growing inclination towards the use of recycled materials, such as composted organic wastes. Consequently, the demand for composts for farming has risen quite significantly. Compost is an environmentally sound natural material obtained when organic waste is reduced to organic fertilizer and soil conditioners through biological processes known as composting [3,4]. While the potential

Manuscript received August 10, 2020. (Write the date on which you submitted your paper for review.). This work was supported by Cape Peninsula University of Technology, University Research Fund Grant no: R166.

N. Ntsobi, N.G.E.R. Etsassala, E. A. Akinpelu, and F. Nchu are in the Department of Horticultural Sciences, Cape Peninsula University of Technology, Bellville Campus, Symphony Way, PO Box 1906, Bellville, 7535, South Africa. (e-mail: NchuF@ cput.ac.za). benefit of compost is unquestionable, ultimately, however, the quality of compost depends on the raw materials and biological processes as well as environmental factors. Hence, there is justifiable interest in finding ways to optimize the quality and yield of end-products of composting. A plethora of studies have reported the use of mechanical and physical interventions including increasing turning frequency of compost heaps, shredding of raw materials, and using ground raw materials to optimize composting process [5-9], On the contrary, fewer studies have explored the use of micro-organisms for the purpose of enhancing the composting process [10-14].

Fungal species are numerous and diverse during both mesophilic and thermophilic phases of composting. Their activities release important plant macro- and micro-nutrients to plants. The composting process depends on the activities of diverse groups of microorganisms such as bacteria and fungi during the breakdown of raw compost materials to humus [12]. The beneficial effects of bacterial and fungal inoculants have been demonstrated by few researchers. Gaur et al. [14] for example, demonstrated that inoculating compost materials made up of jowar stalk, wheat straw (5:3) and jamun leaves with four mesophillic fungi, viz., Aspergillus niger, Aspergillus sp. (R.), Thrichoderma viride and Penicillium sp. reduced the composting period by one month and improved the quality of the composted end-product. In a more recent study reported by Pan et al. [15], three bacterial isolates significantly improved the chemical composition of the end-product of composting. Saprophytic fungi are among groups of microorganisms that breakdown or mineralize organic materials [16]. Some saprophytic fungi use lignocellolosic polymers as the main source of carbon [17]. Lignocellulose is generally considered to be recalcitrant and difficult to decompose and is typically biodegraded by actinomycetes, streptomycetes and some saprophytic fungi. Hence, certain saprophytic fungi play a vital role in the biodegradation and conversion process during composting [5, 12, 18-19].

Interestingly, many entomopathogenic fungi are saprophytes [20]. Saprophytes live on dead or dying material and obtain energy by breaking down organic matter in dead plants and animals [5, 16]. Entomopathogenic fungi are better known for their ability to cause infection to insects and acarines than their bio-enhancing effects on composting [20-21]. It has been reported that Metarhizium anisopliae var. anisopliae, Beauveria

bassiana and Verticilium lecanii (Hypocreales) can produce extracellular enzymes such as endoproteases, aminopeptidases, lipases, esterases and chitinases [22], all of which have pertinent 
roles during composting $[13,23]$. The inclusion of entomopathogenic fungal endophytes to raw materials of composting could enhance the composting process resulting in composting materials that have improved biophysicochemical properties such as high nutrient content, high population of beneficial microbes and low phytotoxicity. To the best of our knowledge, very few studies have focused on the use of entomopathogenic fungus in composting [10]. Hence, this research work, primarily, evaluates the beneficial effects of inoculating organic compost heaps with the entomopathogenic fungus $B$. bassiana during composting on the biophysicochemical properties of the end-product of composting of mixed vegetable solid wastes.

\section{MATERIALS AND METHODS}

\section{A. Solid waste materials and compost heaps}

Disposed vegetable wastes were collected from a Food Market situated at the Shoprite Park in Parow, Cape Town, Western Cape. The vegetable wastes consisted of artichoke, broccoli, spinach, cabbage, lettuce, garlic, basil, carrot, beet, cauliflower, celery, pepper, corn (Zea mays), green bean, cowpea and potato. The collection was done in the morning and the wastes were collected using sanitary hand gloves to avoid contamination. The collected wastes were placed in black polythene bags. It was chopped separately (approx. size 2-4 $\mathrm{cm}^{2}$ ) and then mixed well to form a single big heap. Thereafter, the heap was sub-divided into 10 equal parts to form 10 smaller heaps $($ diameter $=60 \mathrm{~cm}$; height $=25 \mathrm{~cm})$.

\section{B. Fungal isolates}

An indigenous B. bassiana fungal isolate (FRVP/S1) was used in this study. The fungal isolate was isolated from a soil sample originating from a vineyard in the Western Cape Province by baiting of the soil with fifth instar larvae of Cydia pomonella (codling moth) (Insecta) as described in Abaajeh and Nchu [Error! Reference source not found.]. Pure cultures of the isolate are being maintained in the Biology Research Laboratory of the Department of Horticultural Sciences, Cape Peninsula University of Technology.

\section{Culturing of fungi and preparation of fungal treatment}

$B$. bassiana inoculum was obtained by culturing the fungus on plates containing a selective medium, made up of half-strength Potato Dextrose Agar (PDA), $0.02 \mathrm{~g} / \mathrm{L}$ of ampicillin (Sigma-Aldrich (Pty) Ltd, Kempton Park), and $0.04 \mathrm{~g} / \mathrm{L}$ streptomycin (Sigma-Aldrich (Pty) Ltd, Kempton Park) to prevent bacterial growth. Fungal cultures were incubated at 25 ${ }^{\circ} \mathrm{C}$ in the dark for four weeks. Mature conidia were obtained by scraping-off the conidia gently from the surface of the culture. A sub-sample of the harvested conidia was used in a germination test to determine conidial viability according to the method described by Inglis et al. [24]. Briefly, $0.1 \mathrm{~mL}$ of conidial suspension prepared at $1 \times 10^{4}$ conidia/mL and containing $0.01 \%$ Tween 80 was spread-plated on sterile PDA plates and incubated for 24 hours in the dark, and then examined under a light microscope. Conidial germination was determined from 100-conidium counts of four replicates. High spore germination of over $90 \%$ was obtained. Subsequently, the remaining conidia were used to prepare conidial suspension for the fungal treatment. Matured 4 weeks old B. bassiana conidia obtained from the PDA plates were transferred to $2 \mathrm{~L}$ glass bottles containing sterile $0.01 \%$ Tween 80 in water, capped, mixed by agitating the bottle for 5 min by shaking and using a magnetic stirrer (at $20{ }^{\circ} \mathrm{C}, 300 \mathrm{rpm}$ for $30 \mathrm{~min}$ ) to form a homogenous conidial suspension. The conidia concentration was enumerated using a haemocytometer and observed with a light microscope at $40 \mathrm{X}$. In order to obtain the desired $1 \times 10^{4}$ conidia/mL, the volume of sterile $0.01 \%$ Tween was increased or conidia added to the glass bottle.

\section{Experimental setup}

The experiment was conducted under shade in open-air conditions at the nursery in the Department of Horticultural Sciences, Cape Peninsula University of Technology (Bellville Campus). The compost heaps were placed on a flat concrete surface with a black plastic lining. Ten heaps of compost materials consisting of a mixture of the chopped vegetables was each placed 2 meters apart. Five of the heaps were inoculated with $240 \mathrm{~mL}$ of $1 \times 10^{4}$ conidia/mL suspension. The other five heaps each received $240 \mathrm{~mL}$ of $0.01 \%$ Tween 80 in water without the fungal conidia. All the heaps were thoroughly mixed by turning several times. Each of the heaps was randomly allocated to the test or control treatment. The heaps were turned once a week using a spade so as to increase aeration and the oxygen supply to microorganisms. All heaps were uncovered and exposed to natural environmental conditions. Water was supplied to the compost heaps using a watering can. Each composting mixture received $250 \mathrm{~mL}$, and $2.5 \mathrm{~L}$ of sterile water was used in total. Heaps were only watered once after two weeks due to the occurrence of intermittent rain and the fact that the vegetable waste materials had high water content. Heap temperature was monitored daily using a 1-metre long thermometer probe (Major tech [Cape Agricultural Products] Somerset West, Cape Town). The $\mathrm{pH}$ and moisture content of each pile were monitored using 2-in-1 Soil $\mathrm{pH}-$ Moisture Meter with a humidity reference scale of $0-10$ (equivalent to $0-100 \%$ humidity), which was further classified as follows: 0-3 (low humidity), 4-7 (moderate humidity) and 8-10 (high humidity). The data were used to obtain weekly means, which were eventually analysed statistically and are presented as the results. All measurements were taken in the centre of the heaps, avoiding the side walls as these could be influenced by wind and direct sunlight. The ambient environmental conditions temperature and humidity data were also collected. The ambient temperature in the morning ranged from $11-25{ }^{\circ} \mathrm{C}$ and afternoon $\left(16-37{ }^{\circ} \mathrm{C}\right)$; and relative humidity: Morning (38-94\%), afternoon (28-83\%). The experiment ran over a four-week period.

\section{E. End product toxicity assessment:- germination and seedling tests}

Germination and seedling toxicity tests were used to assess composting end-product toxicity on cowpea (Vigna unguiculate L. Walp.). Composted materials obtained from the control and test treatments following four weeks of composting were mixed with coarse river sand obtained from Stanler Farms Nursery Pty. Ltd., Cape Town, in descending amounts as follows: $25 \%$ 
compost $+75 \%$ river sand and $12.5 \%$ compost $+87.5 \%$ river sand by volume. The samples were each placed in a $10 \mathrm{~cm}$ plastic potting cups. Three seeds were sown in each pot for the germination test. For the seedling toxicity test, two seedlings were transplanted into each pot. Composted samples were obtained from three randomly selected heaps belonging to control and test treatments, and each of these heaps had two representing pots. Hence, the germination test comprised a total of 12 pots representing the heaps from the two treatments. Similarly, the seedling test had a total of 12 pots representing the heaps from the two treatments. The samples were watered twice each day and maintained for 8 weeks in a greenhouse under the following conditions: $25-27{ }^{\circ} \mathrm{C}$ day and $70-75 \% \mathrm{RH}$. The number of seeds that germinated and seedlings that were alive after 8 weeks were recorded for each replicate. The percentage of seed germination was determined in relation to the number of cultivated seeds. Similarly, percentage of live seedlings was determined in relation to the number of transplanted seedling.

\section{F. Analytical procedures}

The colour of the compost was observed and classified using the Munsell Book of colour [25] as a reference at the end of the experiment. Chemical analysis of the composted materials was carried out by Bemlab Pty Ltd, Sommerset West, South Africa. The micro-nutrient (B, Fe, $\mathrm{Zn}, \mathrm{Cu}$, and $\mathrm{Mn}$ ) and micro-nutrient $(\mathrm{N}, \mathrm{P}, \mathrm{K}, \mathrm{Ca}, \mathrm{Mg}$ ) contents in one kilogram were determined using the methods by Campbell and Plank [7], Miller [26], Walkley and Black [27] and The Non-affiliated Soil Analyses Work Committee [28] as described in Mtimkulu et al. [29] at the end of the trial.

\section{G. Statistical analysis}

For comparison of the control and treatment groups, the experimental data collected, viz., heap temperature, humidity, compost nutrients contents, number of seeds germinated and number of live seedling were analysed using One-Way ANOVA. The post hoc Tukey test was used to separate the means. Statistical significance was performed at $P=0.05$ level. All statistical analyses were performed using PAST, free statistical software [29]. The values reported in this paper are mean $\pm \mathrm{SE}$.

\section{RESULTS}

\section{A. The effect of fungal treatment on compost heap temperature and heap humidity}

Heap temperature recorded during the duration of the experiment ranged from $18-40.3{ }^{\circ} \mathrm{C}$ for fungus treated material and $17-39.8{ }^{\circ} \mathrm{C}$ for the control from weeks one to four. There was no significant difference $(\mathrm{df}=8 ; \mathrm{p}>0.05)$ in heap temperatures between fungus and control treatments from week one to four after the experiment. However, the highest heap temperature was observed at the third week as $34.88 \pm 2.5^{\circ} \mathrm{C}$ and $33.78 \pm 2.2^{\circ} \mathrm{C}$ in fungus treated and control experiments, respectively as shown in Table $\mathrm{I}$.
TABLE I: VARIATION IN HEAP TEMPERATURE FOLLOWING EXPOSURE TO B. BASSIANA INOCULUM AND CONTROL TREATMENT DURING COMPOSTING OF RAW VEGETABLE WASTE OVER 4-WEEKS COMPOSTING

\begin{tabular}{lll}
\hline Weeks & Fungal treatment & Control \\
\hline 1 & $27.1 \pm 1.0 \mathrm{a}$ & $26.8 \pm 0.9 \mathrm{a}$ \\
2 & $29.3 \pm 1.3 \mathrm{a}$ & $27.7 \pm 1.2 \mathrm{a}$ \\
3 & $34.9 \pm 2.5 \mathrm{a}$ & $33.8 \pm 2.2 \mathrm{a}$ \\
4 & $23.2 \pm 1.7 \mathrm{a}$ & $19.4 \pm 1.0 \mathrm{a}$ \\
\hline
\end{tabular}

Values are mean $\% \pm$ SE. Values followed by the same number in the same row do not show significance at $\mathrm{P}>0.05$ following comparison using Tukey test.

\section{B. Heap Moisture}

Fungal inoculum did not have any significant effect ( $\mathrm{df}=1,8 ; \mathrm{p}$ $>0.05$ ) on heap moisture compared to the control from weeks one to four. The heap moisture contents were consistently high all through the experiment, ranging from $84-97 \%$ on the moisture scale of 1-10 (representing 10-100\%) during the first three weeks. However, the moisture contents dipped to $53 \%$ (test treatment) and 55\% (control treatment) in the composted materials from $90 \%$ and $97 \%$ at the onset of the experiment, respectively (Table II).

TABLE II: PERCENT CHANGE IN HEAP MOISTURE READING (MEAN \pm

SE) FOLLOWING EXPOSURE TO B. BASSIANA INOCULUM AND CONTROL TREATMENT DURING COMPOSTING OF RAW VEGETABLE WASTE OVER 4-WEEKS COMPOSTING

\begin{tabular}{lll}
\hline Weeks & Fungal Treatment $(\%)$ & Control $(\%)$ \\
\hline 1 & $90 \pm 3.2 \mathrm{a}$ & $97 \pm 0.9 \mathrm{a}$ \\
2 & $96 \pm 0.5 \mathrm{a}$ & $96.2 \pm 0.9 \mathrm{a}$ \\
3 & $84.8 \pm 4.1 \mathrm{a}$ & $83.6 \pm 1.8 \mathrm{a}$ \\
4 & $52.95 \pm 2.1 \mathrm{a}$ & $55.48 \pm 2.0 \mathrm{a}$ \\
\hline
\end{tabular}

Values are mean $\% \pm$ SE. Values followed by the same number in the same row do not show significance at $\mathrm{P}>0.05$ following comparison using Tukey test.

\section{C. $p H$ variations}

There was no significant difference in $\mathrm{pH}$ (7) of compost heaps in fungal treated material and the control at week one $(\mathrm{df}=4,11 ; \mathrm{F}=1.357 ; \mathrm{p}=0.3072)$, week two $(\mathrm{df}=4,11 ; \mathrm{F}=$ $0.4792 ; \mathrm{p}=0.5095)$, and week three $(\mathrm{df}=4,11 ; \mathrm{F}=1.141 ; \mathrm{p}=$ $0.3441)$ composting. However, at week four both treatments showed significant variations ( $\mathrm{df}=1,6 ; \mathrm{p}=0.003$ ) for the final product of the composting (test; $8.8 \pm 0.1$ and control; $7.9 \pm$ $0.12)$

(Table III).

TABLE III: PH VARIATIONS FOLLOWING EXPOSURE TO B. BASSIANA INOCULUM AND CONTROL TREATMENT DURING COMPOSTING OF RAW VEGETABLE WASTE OVER 4-WEEKS COMPOSTING

\begin{tabular}{lll}
\hline Weeks & Fungal Treatment & Control \\
\hline 1 & $7 \pm 0.02 \mathrm{a}$ & $7 \pm 0.0 \mathrm{a}$ \\
2 & $7 \pm 0.0 \mathrm{a}$ & $7 \pm 0.0 \mathrm{a}$ \\
3 & $7 \pm 0.0 \mathrm{a}$ & $7 \pm 0.0 \mathrm{a}$ \\
4 & $8.8 \pm 0.1 \mathrm{a}$ & $7.93 \pm 0.1 \mathrm{~b}$ \\
\hline
\end{tabular}

Values are mean $\% \pm$ SE. Values followed by the same number in the same row do not show significance at $\mathrm{P}>0.05$ following comparison using Tukey test.

\section{Changes in colour of the compost during composting}

Changes in colour from green raw materials at the beginning of the experiment to brown (control) and dark brown (fungus treated heaps) colour week four post treatment were observed. Based on the guidelines of the Munsell book of colours [25], 
fungus treated compost was 5 YR 3/3 (dark-brown colour) and control compost was 5 YR 4/4 (brown in colour).

\section{E. Chemical analysis of compost: Macronutrients}

At week four post composting, the levels of $\mathrm{N}, \mathrm{P}, \mathrm{K}$ and $\mathrm{Mg}$ did not differ significantly in fungus treated heaps and the control ( $\mathrm{df}=1,6 ; \mathrm{P}>0.05$ ) (Table 4). However, there was a significant difference $(\mathrm{P}<0.05)$ in $\mathrm{Ca}$ concentration of composted samples obtained from fungus and control treatments; the level of $\mathrm{Ca}$ was significantly higher $(\mathrm{df}=4,11 ; \mathrm{F}$ $=16.21 ; \mathrm{p}=0.007)$ in compost heaps with no fungal inoculum (20502.5 $\pm 1133.9 \mathrm{mg} / \mathrm{kg}$ ) compared to fungus treated compost $(14709.5 \pm 885.4 \mathrm{mg} / \mathrm{kg})$. On the other hand, there was no difference $(\mathrm{P}>0.05)$ in carbon levels between the two treatments.

\section{E. Micronutrients}

End-product of composted samples obtained from heaps exposed to $B$. bassiana inoculum showed significantly $(\mathrm{df}=1,6$; $\mathrm{P}<0.05)$ enriched levels of $\mathrm{Mn}(64.17 \pm 1.47 \mathrm{mg} / \mathrm{kg}), \mathrm{Fe}(173.0$ $\pm 6.9 \mathrm{mg} / \mathrm{kg}), \mathrm{Cu}(7.9 \pm 1.9 \mathrm{mg} / \mathrm{kg})$ and $\mathrm{Zn}(83.08 \pm 9.84 \mathrm{mg} / \mathrm{kg})$ in comparison to compost obtained from the corresponding unexposed heaps; Mn $(53.4 \pm 3.35 \mathrm{mg} / \mathrm{kg}), \mathrm{Fe}(116.1 \pm 14.4$ $\mathrm{mg} / \mathrm{kg}), \mathrm{Cu}(2.4 \pm 0.5 \mathrm{mg} / \mathrm{kg})$ and $\mathrm{Zn}(45.8 \pm 5.1 \mathrm{mg} / \mathrm{kg})($ Table $4)$. On the other hand, there was no difference $(P>0.05)$ in $B$ levels between the two treatments. Similarly, ash particles in both treatments were not statistically different (Table IV). The fungus treated compost had a different $\mathrm{C} / \mathrm{N}$ ratio (9:1) compared to the control (8:1) (Table IV). There was no significant difference $(\mathrm{P}>0.05)$ in $\mathrm{C} / \mathrm{N}$ ratio between the treatments when means were separated using the post hoc Tukey test. The highest $\mathrm{C} / \mathrm{N}$ ratio was recorded in compost heaps with fungal inoculum (9:1).

TABLE IV: THE EFFECT OF TREATMENT WITH B. BASSIANA ON CHEMICAL COMPOSITION OF THE END-PRODUCT OF COMPOSTING OF SOLID VEGETABLE WASTE COMPARED TO CONTROL OVER 4-WEEKS COMPOSTING

\begin{tabular}{lll}
\hline Parameters & Treatment & Control \\
\hline Resistance $($ ohm $)$ & $50 \pm 0.00 \mathrm{a}$ & $50 \pm 0.00 \mathrm{a}$ \\
Density kg/m & $423.46 \pm 30.01 \mathrm{a}$ & $422.85 \pm 31.33 \mathrm{a}$ \\
$\mathrm{N} \%$ & $4.06 \pm 0.20 \mathrm{a}$ & $3.9 \pm 0.20 \mathrm{a}$ \\
$\mathrm{P} \mathrm{mg} / \mathrm{kg}$ & $13908.92 \pm 429.1 \mathrm{a}$ & $10701.2 \pm 1638.2 \mathrm{a}$ \\
$\mathrm{K} \mathrm{mg} / \mathrm{kg}$ & $41197.5 \pm 2174.2 \mathrm{a}$ & $37145.5 \pm 2632.5 \mathrm{a}$ \\
$\mathrm{Ca} \mathrm{mg} / \mathrm{kg}$ & $14709.5 \pm 885.4 \mathrm{a}$ & $20502.5 \pm 1133.9 \mathrm{~b}$ \\
$\mathrm{Mg} \mathrm{mg} / \mathrm{kg}$ & $4206.6 \pm 236.7 \mathrm{a}$ & $4005.9 \pm 228.8 \mathrm{a}$ \\
$\mathrm{Na} \mathrm{mg} / \mathrm{kg}$ & $3637.4 \pm 224.8 \mathrm{a}$ & $4665.5 \pm 324.8 \mathrm{~b}$ \\
$\mathrm{Mn} \mathrm{mg} / \mathrm{kg}$ & $64.2 \pm 1.5 \mathrm{a}$ & $53.4 \pm 3.35 \mathrm{~b}$ \\
$\mathrm{Fe} \mathrm{mg} / \mathrm{kg}$ & $173.0 \pm 6.9 \mathrm{a}$ & $116.1 \pm 14.4 \mathrm{~b}$ \\
$\mathrm{Cu} \mathrm{mg} / \mathrm{kg}$ & $7.9 \pm 1.8 \mathrm{a}$ & $2.4 \pm 0.5 \mathrm{~b}$ \\
$\mathrm{Zn} \mathrm{mg} / \mathrm{kg}$ & $83.1 \pm 9.8 \mathrm{a}$ & $45.8 \pm 5.1 \mathrm{~b}$ \\
$\mathrm{~B} \mathrm{mg} / \mathrm{kg}$ & $55.7 \pm 1.4 \mathrm{a}$ & $58.2 \pm 6.3 \mathrm{a}$ \\
$\mathrm{C} \%$ & $31.4 \pm 0.6 \mathrm{a}$ & $29.5 \pm 2.1 \mathrm{a}$ \\
$\mathrm{Ash} \%$ & $35.2 \pm 1.3 \mathrm{a}$ & $29.5 \pm 2.3 \mathrm{a}$ \\
$\mathrm{C} / \mathrm{N} \mathrm{ratio}$ & $9: 1 \pm 0.59 \mathrm{a}$ & $8: 1 \pm 0.94 \mathrm{a}$ \\
\hline
\end{tabular}

Values are mean $\% \pm \mathrm{SE}$. (standard error). Values followed by the same letter in a row do not show significance at $\mathrm{P}>0.05$ following comparison using Tukey test.

\section{F. End product toxicity assessment-Germination and seedling test}

When tested from 12.5-25\%, composted materials from fungus inoculated heaps were toxic to cowpea seeds. At 25\%,
$58 \%$ success in seed germination was obtained in the control treatment. Nonetheless, when compost contents in the growth medium were reduced to $12.5 \%$, the seed germination was improved, reaching $65 \%$ germination in the fungus treated materials. In the seedling test, all seedlings (100\%) in the control treatment were alive when compost end-products were used at 12.5 and $25 \%$. Symptoms of yellowing around the leaf edges were noticeable in seedlings cultivated in medium containing $25 \%$ composted materials from fungus treated heaps (Table V).

TABLE 5: PERCENTAGE OF SEED GERMINATION AND SEEDLING GROWTH OF VIGNA UNGUICULATA IN RESPONSE TO B. BASSIANA INOCULUM AND CONTROL TREATMENT AFTER COMPOSTING OF SOLID VEGETABLE WASTE UNDER GREENHOUSE CONDITIONS

\begin{tabular}{lcccc}
\hline \multirow{2}{*}{$\begin{array}{l}\text { Growth media } \\
\text { Concentration }\end{array}$} & \multicolumn{2}{c}{$\begin{array}{c}\text { Percentage of seed } \\
\text { germination }\end{array}$} & \multicolumn{2}{c}{$\begin{array}{c}\text { Percentage of seedling } \\
\text { growth }\end{array}$} \\
\cline { 2 - 5 } & Treatment & Control & Treatment & Control \\
\hline $\begin{array}{l}25 \% \text { compost }+ \\
75 \% \text { river sand }\end{array}$ & $0 \mathrm{a}$ & $58 \mathrm{~b}$ & $75 \mathrm{a}$ & $100 \mathrm{~b}$ \\
$\begin{array}{l}12.5 \% \text { compost }+ \\
87.5 \% \quad 65 \mathrm{a}\end{array}$ & $80 \mathrm{a}$ & $75 \mathrm{a}$ & $100 \mathrm{~b}$ \\
sand) & & & & \\
\hline
\end{tabular}

Means with same lowercase letters in the same row in either seed germination or seedling growth are not significantly different following Tukey test at $\mathrm{P}=0.05$ level of significance

\section{DISCUSSION}

\section{A. Temperature and humidity}

Treatment of mixed vegetable waste materials with $B$. bassiana inoculum did not significantly affect the physical parameters (heap temperature and heap humidity) in this study. The highest average weekly temperature recorded was $34.8^{\circ} \mathrm{C}$, which was relatively lower when compared to other similar studies [30-31]. Gaur et al. [14] observed maximum temperatures of $45{ }^{\circ} \mathrm{C}$ and $51{ }^{\circ} \mathrm{C}$ during composting of the mixture of jowar stalk and wheat straw, and jamun leaves inoculated with Aspergillus niger and Trichoderma viride, respectively. However, the influence of the experimental conditions, such as heap size, ambient temperature and humidity and turning frequencies on the composting process and the outcomes cannot be under estimated [32]. In this study, the small size of the heaps, high water content of the solid vegetable wastes, evaporation, tree shading of the composted area, and the frequent turning of the heaps could have contributed to the low heap temperature. Temperature is a key parameter in composting, as it indicates the state of decomposition and guarantees sanitation of the end product [29]. In the present study, the temperature increased from the first to third week before dropping in the fourth week; although the experiment was ran for four weeks. The rise and drop in temperature suggests that the composting process might have gone through the three phases: The mesophilic, thermophilic and maturation. The other important physical parameter that was assessed in this study was the moisture content, which was consistently high in the heaps during the first three weeks of composting, and did not appear to be affected by the fungal inoculation. This was expected, though, since fresh vegetable wastes with high organic waste [33]. Physical properties, such as color, texture and porosity are affected by moisture content as well. During 
the fourth week of this study, the humidity decreased to $50 \%$, which was within the optimum range for composting [33].

\section{B. Nutrient contents}

The results of this current study suggest that fungal inoculation of vegetable composting materials influence chemical properties of end product of composting, especially micronutrient contents. Remarkably higher levels of $\mathrm{Fe}, \mathrm{Zn}, \mathrm{Mn}$ and $\mathrm{Cu}$ occurred in composted materials from fungus treated heaps than in those from control treated heaps. Previously, Jusoh et al. [34] reported increased accumulation of heavy metals ( $\mathrm{Fe}$ and $\mathrm{Zn}$ ) during composting of rice straw using effective microorganisms (a microbial solution) as an accelerator. Paré et al. [35] also reported increased accumulation of heavy metals ( $\mathrm{Fe}$ and $\mathrm{Zn}$ ) during composting of biosolids. It is believed that increased heavy metal levels in composted materials indicate maturity and stability of the end product of composting. Unfortunately, heavy metals, which are referred to as trace metals because they are needed in small quantities by plants can cause phytotoxicity at high concentration [36]. Thus, the inoculation of compost heaps with fungal inoculum may have other unintended negative consequences that should be investigated further. However, the chemical forms of the heavy metals influence their bioavailability more than their total metal contents [37]. Paré et al. [35] demonstrated that co-composting biosolids and municipal solid wastes substantially reduces the extractability and exchangeability of some heavy metals. On the other hand, besides $\mathrm{Ca}$, macronutrients $(\mathrm{N}, \mathrm{P}, \mathrm{K}$, ) were not significantly influenced by exposing plants to $B$. bassiana inoculum. Higher $\mathrm{Ca}$ content was detected in the control treatment compared to the fungus treatment. This finding is different from that of Jusoh et al. [34], who reported that composting of rice straw with a solution of effective microorganisms resulted in significantly more $\mathrm{N}, \mathrm{P}$ and $\mathrm{K}$ contents $(\mathrm{P}<0.05)$ in composted materials compared to compost without microorganisms. There was no significant difference in $\mathrm{C} / \mathrm{N}$ ratio in this study; the values for the composted materials were 9:1 for fungus treatment and 8:1 for control treatment. These values were not far-off from the ideal compost $\mathrm{C} / \mathrm{N}$ ratio, which ranged from 13:1 to 10:1 [30]. The detection of high heavy metals in the fungus treatment demonstrates that the fungus inoculum increased decomposition of the organic waste. This assertion is further supported by the dark brown colour of the fungus treated heaps. Mature compost heaps turn to have a dark brown colour [38]. While there was no significant difference in $\mathrm{pH}$ level (7) during the first three weeks of composting in control and test heaps, the $\mathrm{pH}$ levels significantly differed at week four; 8.75 (fungus treatment) and 7.95 (control). According to Chen et al. [36], optimum compost $\mathrm{pH}$ ranges from 6.8-7.3. High alkalinity of compost may hinder release of macronutrients to plants.

The composted samples from fungus treated heaps were relatively more toxic to cow pea seeds and seedlings than those from the control, especially when the composted samples from the fungus treated heaps were used at high proportion in a potting soil mix. This could be linked to the high micronutrients contents. However, when composted materials were used at a reduced amount (12\%) in a potting soil mix, toxicity on cowpea seeds and seedlings diminishes substantially while germination and seedling survival increased significantly. Micronutrients are phytotoxic to plants at high concentrations [36]. Classical symptoms of micronutrient toxicity, including chlorosis and scorching of leaves were observed in this study.

\section{CONCLUSION}

In conclusion, B. bassiana inoculum causes a significant increase of micronutrient contents in composted materials following composting of vegetable wastes. It is interesting to know that entomopathogenic fungi, which are best known for control of insects, might also be useful as an amendment of the composting of organic vegetable wastes. However, the study also cautions that composted material from fungus treated heaps might be phytotoxic if used at high proportion. Further investigations to assess potential risks of phytotoxicity and mycotoxins of these fungi in compost end products, and the effects of fungi on changes in enzyme activities during composting are warranted.

\section{ACKNOWLEDGMENT}

The authors are grateful to Cape Peninsula University of Technology for supporting this project financially through the University Research Fund (R166). We thank the management and staff of Fruit \& Veg Market, Parow, Cape Town for supplying vegetable waste materials. Our gratitude goes to $\mathrm{Mr}$ Terrence Hlokane Mabela and Mr Mvuyisi Mtshisazwe for collecting and transporting the vegetable waste materials.

\section{REFERENCES}

[1]K. Klonsky, "Forces impacting the production of organic foods," Agriculture and Human Values, vol. 17, pp. 233-243, 2020. https://doi.org/10.1023/A:1007655312687

[2]V. Seufert, N. Ramankutty, and J.A. Foley, "Comparing the yields of organic and conventional agriculture," Nature, vol. 485, pp. 229-232, 2012. https://doi.org/10.1038/nature11069

[3]A.R. Abaajeh, and F. Nchu, "Isolation and pathogenicity of some South African entomopathogenic fungi (Ascomycota) against eggs and larvae of Cydia pomonella (Lepidoptera: Tortricidae)," Biocontrol Science and Technology, vol. 25, no. 7, pp. 828-842, 2015. https://doi.org/10.1080/09583157.2015.1019831

[4]R. Alexander, "Compost markets grow with environmental applications," Biocycle, vol. 40, pp. 43-46, 1999.

[5]P. Baldrian, and V. Valášková, "Degradation of cellulose by basidiomycetous fungi," FEMS microbiology reviews, vol. 32, no. 3, pp. 501-21, 2008. https://doi.org/10.1111/j.1574-6976.2008.00106.x

[6]M.D. Baltimore, "Munsell book of colour. Macbeth," Division of Kollmorgen Corp, 1976.

[7]C.R. Campbell, and C.O. Plank, "Preparation of plant tissue for laboratory analysis," In: Kalra, Y.P. (eds.) Handbook of Reference Methods for Plant Analysis, CRC Press, Boca Raton, FL, pp. 13, 1997. https://doi.org/10.1201/9781420049398.ch3

[8]N. Chatterjee, M. Flury, C. Hinman, and C.G. Cogger, "Chemical and physical characteristics of compost leachates-A Review " (No. WA-RD 819.1), pp. 7-43, 2013.

[9]S. Chaturvedi, B. Singh, L. Nain, S.K. Khare, A.K. Pandey, and S. Satya, "Evaluation of hydrolytic enzymes in bioaugmented compost of Jatropha cake under aerobic and partial anaerobic conditions," Annals of Microbiology, vol. 60, no. 4, pp. 685-691, 2010. https://doi.org/10.1007/s13213-010-0113-5

[10] L. Chen, A. Moore, and M.D. de Haro-Marti, "Dairy compost production and use in Idaho: On-Farm Composting Management," CIS, 11902012. 
Accessed $\quad$ on $\quad 08 \quad$ August 2018.

http://www.extension.uidaho.edu/nutrient/pdf/On

Farm\%20Composting\%20Managment.pdf.

[11] E.H. Clifton, S.T. Jaronski, B.S. Coates, E.W. Hodgson, and A.J. Gassmann, "Effects of endophytic entomopathogenic fungi on soybean aphid and identification of Metarhizium isolates from agricultural fields," PloS one, vol. 3, no. 3, e0194815, 2018. https://doi.org/10.1371/journal.pone.0194815

[12] P. Partanen, J. Hultman, L. Paulin, P. Auvinen, M. Romantschuk, "Bacterial diversity at different stages of the composting process," $B M C$ Microbiology, vol. 10, no. 94, 1-11, 2010. https://doi.org/10.1186/1471-2180-10-94

[13] É.K. Fernandes, V.R. Bittencourt, and D.W. Roberts, "Perspectives on the potential of entomopathogenic fungi in biological control of ticks," Experimental Parasitology, vol. 130, no. 3, pp. 300-5. 2012. https://doi.org/10.1016/j.exppara.2011.11.004

[14] A.C. Gaur, K.V. Sadasivam, R.S. Mathur, and S.P. "Magu, Role of mesophilic fungi in composting," Agricultural Wastes, vol. 4, no. 6, 453-460, 1982. https://doi.org/10.1016/0141-4607(82)90040-3

[15] I. Pan, B. Dam, and S.K. Sen, "Composting of common organic wastes using microbial inoculants," Biotechnology, vol. 2, no. 2, 127-134, 2012. https://doi.org/10.1007/s13205-011-0033-5

[16] W. Hou, B. Lian, H. Dong, H. Jiang, and X. Wu, "Distinguishing ectomycorrhizal and saprophytic fungi using carbon and nitrogen isotopic compositions," Geoscience Frontiers pp. 351-356, 2012. https://doi.org/10.1016/j.gsf.2011.12.005

[17] T. Getahun, A. Nigusie, T. Entele, T. Van Gerven, and B. Van der Bruggen, "Effect of turning frequencies on composting biodegradable municipal solid waste quality," Resources, Conservation and Recycling, vol. 65, pp. 79-84, 2012. https://doi.org/10.1016/j.resconrec.2012.05.007

[18] E.A. Hobbie, S.A. Macko, H.H. Shugart, "Insights into nitrogen and carbon dynamics of ectomycorrhizal and saprotrophic fungi from isotopic evidence," Oecologia, vol. 118, pp. 353-360, 1999. https://doi.org/10.1007/s004420050736

[19] J.D. McMillan, B.L. Boynton, "Arabinose utilization by xylose-fermenting yeasts and fungi," Applied biochemistry and biotechnology, vol. 45, pp. 569-584, 1994. https://doi.org/10.1007/BF02941831

[20] U.C. Gupta, and S.C. Gupta, "Trace element toxicity relationships to crop production and livestock and human health: Implications for management," Communications in Soil Science and Plant Analysis, vol. 29, pp. 1491-1522, 1998. https://doi.org/10.1080/00103629809370045

[21] Ø, Hammer, D.A.T. Harper, P.D. Ryan, "Paleontological statistics software: Package for education and data analysis," Palaeontologia Electronica, vol. 4, pp. 1-9, 2001.

[22] E.G. Fernandes, H.M. Valerio, T. Feltrin, and S.T. Van Der Sand, "Variability in the production of extracellular enzymes by entomopathogenic fungi grown on different substrates," Brazilian Journal of Microbiology, vol. 43, no. 2, pp. 827-833, 2014. https://doi.org/10.1590/S1517-83822012000200049

[23] R.J. St Leger, R.M. Cooper, and A.K. Charnley, "Cuticle-degrading enzymes of entomopathogenic fungi: regulation of production of chitinolytic enzymes," Microbiology 132(6):1509-1517, 1986. https://doi.org/10.1099/00221287-132-6-1509

[24] G.D. Inglis, D.L. Johnson, and M.S. Goettel, "Field and laboratory evaluation of two conidial batches of Beauveria bassiana (Balsamo) Vuillemin against grasshoppers," The Canadian Entomologist, vol. 129, no.1, pp.171-186, 1997. https://doi.org/10.4039/Ent129171-1

[25] R.A.V. Rossel, B. Minasny, P. Roudier, and A.B. Mcbratney, "Colour space models for soil science," Geoderma, vol. 133, no. 3, pp. 320-337, 2006 https://doi.org/10.1016/j.geoderma.2005.07.017

[26] F.C. Miller, "Composting of municipal solid waste and its components," Microbiology of Solid Waste, pp. 115-154, 1996. https://doi.org/10.1201/9780138747268-4
[27] A. Walkley, and I.A. Black, "An examination of the degtjareff method for determining soil organic matter, and a proposed modification of the chromic acid titration method," Soil Science, vol. 37, no. 1, 29-38, 1934. https://doi.org/10.1097/00010694-193401000-00003

[28] The Non-Affiliated Soil Analysis Work Committee.: Handbook of standard soil testing methods for advisory purposes. Soil Science Society of South Africa, Pretoria, 1990.

[29] Y. Mtimkulu, A.H. Meyer, A.R. Mulidzi, P.L. Shange, F. Nchu, "Assessing and monitoring the effects of filter material amendments on the biophysiochemical properties during composting of solid winery waste under open field and varying climatic conditions," Waste Management, vol. 57, pp. 59-69, 2017. https://doi.org/10.1016/j.wasman.2016.10.042

[30] N.D.Q. Ribeiro, T.P. Souza, L.M.A.S. Costa, C.P.D. Castro, E.S. Dias, "Microbial additives in the composting process," Ciência e Agrotecnologia, vol. 41, no. 2, pp. 159-168, 2017. https://doi.org/10.1590/1413-70542017412038216

[31] C. Sundberg, and H. Jönsson, "Process inhibition due to organic acids in fed-batch composting of food waste-influence of starting culture," Biodegradation vol. 16, pp. 205-213, 2005. https://doi.org/10.1007/s10532-004-0628-1

[32] A.S. Kalamdhad, and A.A. Kazmi, "Effects of turning frequency on compost stability and some chemical characteristics in a rotary drum composter," Chemosphere vol. 74, no. 10, pp. 1327-1334, 2009. https://doi.org/10.1016/j.chemosphere.2008.11.058

[33] G.A. Ogunwande, J.A. Osunade, K.O. Adekalu, and L.A.O. Ogunjimi, "Nitrogen loss in chicken litter compost as affected by carbon to nitrogen ratio and turning frequency," Bioresource Technology, vol. 99, no. 16, pp. 7495-7503, 2008. https://doi.org/10.1016/j.biortech.2008.02.020

[34] M.L.C. Jusoh, L.A. Manaf, and P.A. Latiff, "Composting of rice straw with effective microorganisms (EM) and its influence on compost quality," Iranian Journal of Environmental Health Science \& Engineering, vol. 10, pp. 17, 2013. https://doi.org/10.1186/1735-2746-10-17

[35] T. Paré, H. Dinel, and M. Schnitzer, "Extractability of trace metals during co-composting of biosolids and municipal solid wastes," Biology and Fertility of Soils vol. 29, pp. 31-37, 1999. https://doi.org/10.1007/s003740050521

[36] I. Petric, E. Avdihodžić, and N. Ibrić, "Numerical simulation of composting process for mixture of organic fraction of municipal solid waste and poultry manure," Ecological Engineering, vol. 75, pp. 242-249, 2015 https://doi.org/10.1016/j.ecoleng.2014.12.003

[37] P. Raath, and C. Schutte, "Guidelines for monitoring soil fertility, plant nutrient status and compost quality in organic wine grape production systems," WineLand, pp. 90-94, 2001.

[38] S. Sarkar, S. Pal, and S. Chanda, "Optimization of a vegetable waste composting process with a significant thermophilic phase," Procedia Environmental Sciences, vol. 35, pp. 435-440, 2016.

https://doi.org/10.1016/j.proenv.2016.07.026

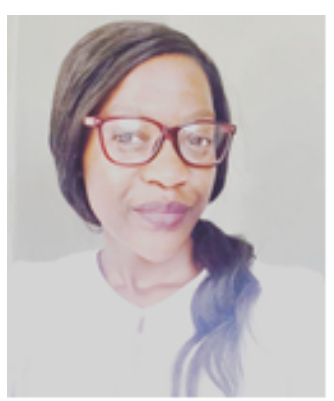

Nomfusi Ntsobi was born and raised in Nyanga Township, Cape Town, Western Cape, South Africa. Nyanga is one of the poorest areas in Cape Town. However, despites numerous obstacles, she is determined to achieve her academic goal of becoming an agricultural scientist and farmer. She obtained a BTech degree in Horticulture from the Cape Peninsula University of Technology (CPUT), South Africa and is pursuing a Master's degree in the Department of Agriculture, Faculty of Applied Sciences, Cape Peninsula University of Technology. Her Research interests include composting of agricultural wastes, crop cultivation, bioactivities of plants and entomopathogenic fungi. Ntsobi has made academic presentations in many community and academic forums. She is also a community leader. 